\section{Micropropagation of Eight Moroccan and French Olive Cultivars}

\author{
Saïda Sghir \\ Equipe Olivier, Département d'Arboriculture, Ecole Nationale d'Agriculture \\ de Meknès BP S/40, 50000 Meknès, Morocco
}

\section{Philippe Chatelet}

UMR BEPC. Equipe Architecture et Fonctionnement des Espèces Fruitières

INRA, Agro M., Montpellier, France

\section{Noureddine Ouazzani \\ Equipe Olivier, Département d'Arboriculture, Ecole Nationale d'Agriculture de Meknès BP S/40, 50000 Meknès, Morocco}

\author{
Françoise Dosba \\ UMR BEPC, Equipe Architecture et Fonctionnement des Espèces Fruitières \\ INRA, Agro M., Montpellier, France
}

\section{Ilham Belkoura ${ }^{1}$ \\ Equipe Olivier, Département d'Arboriculture, Ecole Nationale d'Agriculture de Meknès BP S/40, 50000 Meknès, Morocco}

\begin{abstract}
Additional index words. genotype effect, growth regulators, in vitro, microcutting, Olea
\end{abstract} europaea, rooting

\begin{abstract}
The responses of several Moroccan and French olive (Olea europaea L.) cultivars to various strategies for in vitro establishment and culture were compared.A cultivar effect was clearly observed with 'Haouzia' cultivar being more readily multiplied. ZR produced the best response in all the cultivars studied, in particular when considering the time elapsed between explant inoculation and budbreak for $50 \%$ of the explants (lag phase), growth of the primary shoot and the multiplication rate. Treatments with BA alone or combined with NAA increased the number of axillary buds and internodes without improving their growth. Root induction with IBA in the dark using a two-phase scheme resulted in the best rooting rate in shoots obtained in vitro, and this for all cultivars. Chemical names used: 6-benzyladenine (BA), indole-3-butyric acid (IBA), alpha-naphthalene acetic acid (NAA), zeatin riboside (ZR).
\end{abstract}

More than $70 \%$ of olive trees multiplied in the circum-mediterranean area are propagated through semi-hardwood cuttings (Cimato, 1999). Although this technique ensures genetic homogeneity, it cannot be successfully applied to difficult-to-root cultivars and the demand for healthy planting material, particularly in respect to viral contamination (Martelli et al., 2001), is currently not met.

Micropropagation, as a possible solution, has been relatively recently applied to olive multiplication. Previous studies have illustrated the difficulties inherent to applying a universal multiplication scheme and underlined the heterogeneity of the responses obtained (Bartolini et al., 1990; Garcia-Fèrriz et al., 2002; Leva et al., 1992; Rugini and Fontanazza, 1981). In fact, in vitro multiplication efficiency

Received for publication 17 Feb. 2004. Accepted for publication 31 May 2004. Paper presented as partial requirement for obtaining a $\mathrm{PhD}$ degree by S. Sghir. This work was completed within the framework of the project Projet de Recherche Agronomique pour le Développement 01-13. We thank Boutaïna Mokhless and Chantal Brachet for their expert technical assistance, and Mike Jones for English reviewing.

${ }^{1}$ To whom reprint requests should be addressed; e-mail bilham@enameknes.ac.ma. in olive is related mainly to both genotype (Mencuccini and Rugini, 1994; Rugini and Pannelli, 1993) and culture medium (Cozza et al., 1997; Grigoriadou, 2002; Rugini, 1984; Santos et al., 2003), particularly growth regulators (Chaari Rkhiss et al., 2003; Rugini and Fedeli., 1990) and carbon source (Garcia et al., 2002; Leva et al., 1994). Studies on these parameters have been limited to a small range of olive cultivars (Rugini, 1984; Wallali, 1993; Zuccherelli and Zuccherelli, 2002) including only a few southern mediterranean clones. As a result, little data on the micropropagation potential of these clones is available.

The study reported here present original data concerning the responses of eight Moroccan and French olive cultivars to different strategies for in vitro establishment, and attempts to highlight factors likely to improve in vitro multiplication rates. It also includes possible multiplication schemes for these cultivars.

\section{Materials and Methods}

Plant material. Eight among interesting Moroccan and French olive cultivars, differing in their response to semi-hardwood cutting (Barranco et al., 2000; Sghir et al., 2003), were used in these studies: two easy-to-root cultivars ('ZDH4' and 'Lucques'), four cultivars with medium rooting ability ('Haouzia and 'Dahbia', two traditional Moroccan cultivars, and the French cultivars 'Amellau', and 'Salonenque'), and finally 'Picholine marocaine'and 'Picholine du Languedoc', as difficult-to-root cultivars. The local types 'ZDH4' and 'Picholine marocaine' were found during searches conducted in north Morocco (Ouazzani et al., 1996).

Although no obvious virus symptoms were observed on the mother plants, actual virus status was not determined which, especially in terms of latent viruses (OEPP/EPPO, 1997), might impact on the plant rooting ability as recorded in other species (e.g., Kano and Nagata, 1999).

Nodes were taken from 1-year growth in young plants originating from semi-hardwood cuttings and grown either in a glasshouse and regularly sprayed with fungicide (French cultivars) or under open shade (Moroccan cultivars).

Methods. Two disinfection methods were used. In Moroccan cultivars, explants were prepared as described by Rugini and Fontanazza (1981) whereas an unpublished protocol (Brachet, personal communication) designed and routinely performed in the laboratory was used for French cultivars: $70 \%$ ethanol (1 min), mercryl ( $1 \mathrm{~min}$ ), and $2 \%$ calcium hypochlorite (3 min). Both disinfection procedures were followed by three 10-min washes with sterile distilled water.

Shoot growth was induced from single node explants using cultivation on Rugini basal medium (Rugini, 1984) with $3 \%$ sucrose, autoclaved for $20 \mathrm{~min}$ at $121^{\circ} \mathrm{C}$. Growth regulators (BA, NAA, ZR) were added as necessary.

Cultures were maintained under fluorescent light $\left(40 \mu \mathrm{mol} \cdot \mathrm{m}^{-2} \cdot \mathrm{s}^{-1}\right)$ following a 16 -h photoperiod with a matching $25 / 22^{\circ} \mathrm{C}$ thermoperiod.

In vitro shoots were rooted in OM medium (Rugini, 1984) containing 5.37 $\mu$ M NAA or 24.6 $\mu \mathrm{M}$ IBA (single phase) or with a two-phase protocol developed in the laboratory (after Druart, 1997) with a 5-d induction phase in liquid 24.6 $\mu \mathrm{M}$ IBA solution in the dark with further cultivation on regulator-free Rugini medium.

The following data were recorded in the growth phase one month after culture initiation: the time elapsed between explant inoculation and budbreak for $50 \%$ of the explants, hereafter called the lag phase; the mean number of shoots originating from a single node; the growth recorded as the mean length of in vitro developed shoots; the mean number of internodes per in vitro shoot; and the number of subcultured shoots 1 month after culture initiation.

Rooting response was evaluated 1 month after rooting initiation and expressed as the mean rooting and callusing rates, the mean root number and length, and the mean leaf pair number.

Data were analyzed by ANOVA (Statistica (version 6) Statsoft) and means were separated using Newman and Keuls test (Miller, 1981) at a 0.95 confidence level. Alternatively, a chi-square homogeneity test was performed 


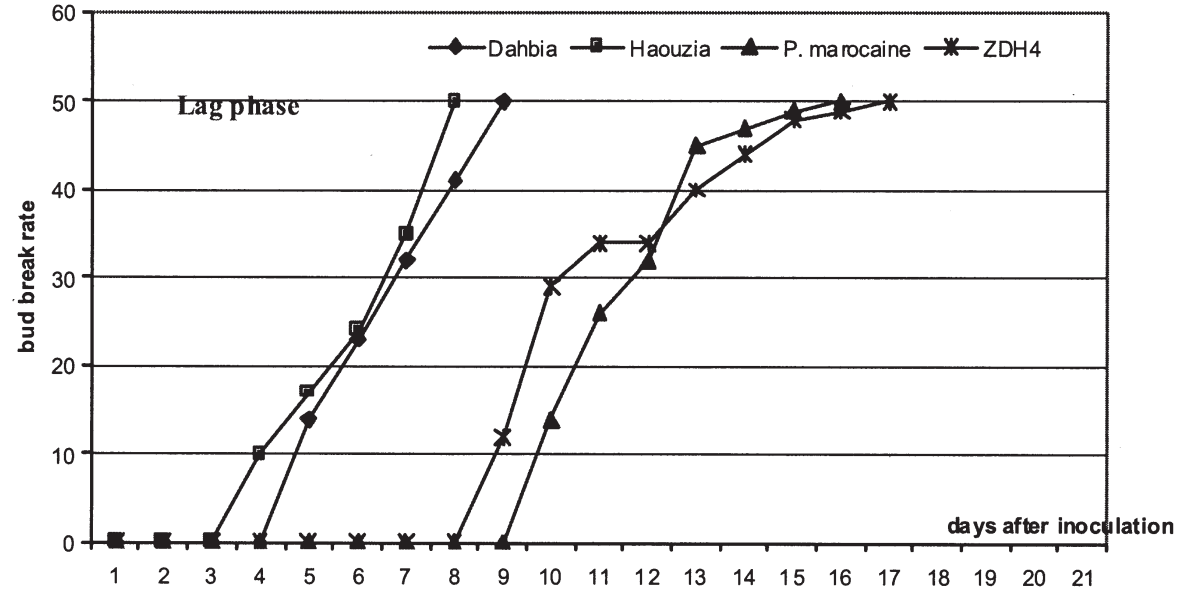

Fig. 1. Budbreak rate over time after culture initiation

Table 1. Growth parameters ${ }^{\mathrm{z}}$ in four Moroccan olive cultivars.

\begin{tabular}{lccl}
\hline Cultivar & SN & SL $(\mathrm{mm})$ & MIN \\
\hline Dahbia & $1.5 \mathrm{ab}^{\mathrm{y}}$ & $15 \mathrm{a}$ & $2.3 \mathrm{ab}$ \\
Haouzia & $2.0 \mathrm{~b}$ & $23 \mathrm{~b}$ & $2.5 \mathrm{~b}$ \\
Picholine marocaine & $1.7 \mathrm{~b}$ & $20 \mathrm{~b}$ & $1.8 \mathrm{a}$ \\
ZDH4 & $1.0 \mathrm{a}$ & $14 \mathrm{a}$ & $1.8 \mathrm{a}$ \\
\hline
\end{tabular}

${ }^{\mathrm{z}} \mathrm{SN}=$ average shoot number, $\mathrm{SL}=$ mean shoot length, $\mathrm{MIN}=$ mean internode number.

${ }^{y}$ Means followed by different letters within the same column are significantly different according to a Newman and Keuls test at 5\% error level

when appropriate.

All results were taken from 10 different explants per treatment (complete randomisation) and all experiments conducted in duplicate unless otherwise indicated.

\section{Results}

In vitro multiplication. Results for in vitro mutiplication under our conditions varied depending on the cultivar and the treatment tested.

Genotype aptitude for in vitro multiplication. Microcutting results showed that the tested cultivars varied in their response since multiplication rates ranged from 0.4 (' $\mathrm{Sa}$ lonenque', 'Amellau', 'Lucques') to 3 ('Haouzia') with intermediate values for 'Picholine du Languedoc' (0.7), 'Dahbia' and 'ZDH4' (1) and 'Picholine marocaine'(2). Variations between cultivars were also observed in the four Moroccan cultivars when recording the lag phase and the growth parameters (Fig. 1, Table 1).

The 'Haouzia' and 'Dahbia' cultivars showed a very early axillary budbreak (4 to $5 \mathrm{~d}$ after inoculation) with a corresponding lag phase reached in 7 and $8 \mathrm{~d}$ after culture initiation. By contrast, buds in 'ZDH4' and 'Picholine marocaine' were observed to break only after 2 weeks with 16- and 17-d lag phases respectively (Fig. 1).

As far as growth parameters are concerned, the highest figures were obtained with the 'Haouzia' cultivar (Table 1). Average axillary bud number per node reached 2 and 1.75 for 'Haouzia' and 'Picholine marocaine' respec- lower cytokinin concentration (Table 3 )

Genotype response to in vitro rooting. In vitro shoots were rooted using two different protocols as described previously.

In the single phase rooting experiment, NAA stimulated root formation only in "Picholine marocaine" cultivar whereas IBA-containing treatments gave rise to variously sized calli at the base of the explants, without root formation.

By contrast, the two-phase protocol produced various rooting percentages in all genotypes (Table 4 and Fig. 3). The highest rate was observed in 'Salonenque' (70\%) and 'Picholine marocaine' (65\%). The 'Haouzia', 'Dahbia' and 'ZDH4' cultivars reached about 50\% rooting, Picholine de Languedoc reached $40 \%$ rooting while 'Lucques' and 'Amellau' never exceeded $30 \%$ root formation. Callusing was high for all cultivars, ranging between $70 \%$ (e.g., 'Haouzia') and $100 \%$ (e.g., 'Salonenque').

If all genotypes are considered, the average root number was 3.2 (reaching 5 in 'Picholine marocaine') for a $2 \mathrm{~cm}$ mean length (reaching 4 in 'Salonenque'). The average number of newly formed leaves ranged from three pairs in the 'Haouzia' variety to two pairs in 'Salonenque' and 'Picholine marocaine' and 1 for all remaining cultivars.

\section{Discussion} clearly increased the multiplication response in all tested cultivars (Table 2). No significant interaction treatment $\times$ genotype was observed when considering effects on mean shoot and internodes numbers, while significant interaction was found when considering effects on mean growth and multiplication rate. However, F values for mean treatment effect were always more important in proportion to variety $\times$ treatment interaction effects and even to variety effect (data not provided). When pooling data from the different varieties, the best results were obtained with ZR treatment, which produced a shorter lag phase $(7 \mathrm{~d})$, the best shoot growth ( $32 \mathrm{~mm}$ mean length with 3 internodes), the highest mean number of buds developed (2) and a maximum multiplication rate of 4. Treatments with BA, combined or not with NAA, decreased lag phase length and improved axillary budding in comparison to the control, but without any shoot growth improvement (Fig. 2B).

The effect of ZR was tested using two concentrations on all four French cultivars. Using a chi-square test at a $5 \%$ error level, no significant difference was observed in the multiplication rate between the two treatments or between the cultivars. However, callus formation at the explant base was substantially reduced at the

Table 2. Growth regulators effects on several in vitro multiplication parameters ${ }^{\mathrm{z}}$ in the Moroccan cultivars.

\begin{tabular}{llccc}
\hline Treatment & SN & SL $(\mathrm{mm})$ & MIN & MR \\
\hline Control (no growth regulator) & $1 \mathrm{a}^{\mathrm{y}}$ & $12.0 \mathrm{a}$ & $1.5 \mathrm{a}$ & $0 \mathrm{a}$ \\
BA $(8.8 \mu \mathrm{M})$ & $2 \mathrm{~b}$ & $13.4 \mathrm{a}$ & $2.3 \mathrm{~b}$ & $2 \mathrm{~b}$ \\
BA $(8.8 \mu \mathrm{M})$ plus NAA $(0.26 \mu \mathrm{M})$ & $1.5 \mathrm{a}$ & $14.8 \mathrm{a}$ & $2.0 \mathrm{ab}$ & $2 \mathrm{~b}$ \\
ZR $(13.6 \mu \mathrm{M})$ & $2 \mathrm{~b}$ & $32.0 \mathrm{~b}$ & $3.0 \mathrm{~b}$ & $4 \mathrm{c}$ \\
\hline
\end{tabular}

${ }^{\mathrm{z}} \mathrm{SN}=$ average shoot number, $\mathrm{SL}=$ mean shoot length, $\mathrm{MIN}=$ mean internode number, $\mathrm{MR}=$ multiplication rate.

${ }^{y}$ Data from 20 explants per genotype $\times$ treatment combination. Means followed by different letters within the same column are significantly different according to a Newman and Keuls test at 5\% error level. 

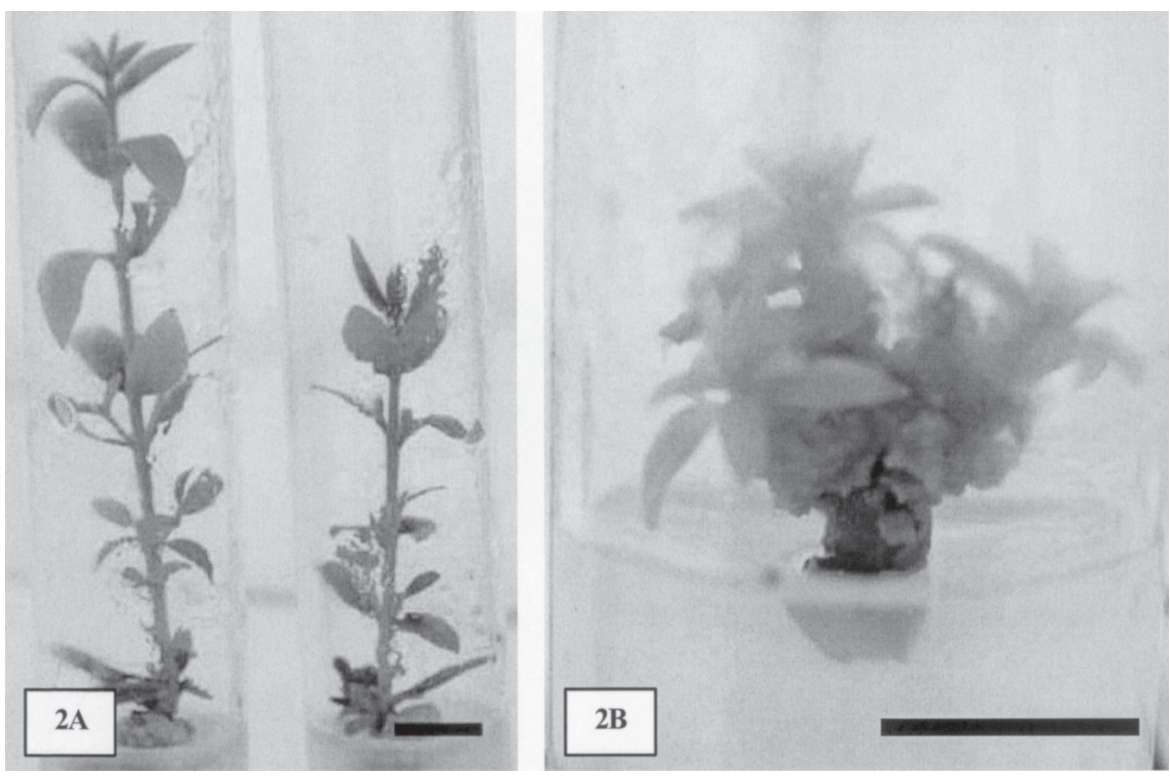

Fig. 2. Effect of growth regulators treatment on growth length (A) and budbreak (B) 1 month after subculture. Bars $=1 \mathrm{~cm}$

Table 4. Response to in vitro rooting of olive varieties following the two-phase protocol. ${ }^{2}$

\begin{tabular}{lcrccc}
\hline Cultivar & $\% \mathrm{R}$ & $\% \mathrm{C}$ & MRN & MRL & MLN \\
\hline Amellau & 20 & 70 & 2.0 & 2.0 & 1 \\
Dahbia & 54 & 80 & 3.0 & 1.3 & 1 \\
Haouzia & 57 & 70 & 3.0 & 1.8 & 3 \\
Lucques & 30 & 80 & 3.5 & 0.8 & 1 \\
P. marocaine & 65 & 100 & 5.0 & 2.5 & 2 \\
P. du Languedoc & 40 & 70 & 3.5 & 1 & 1 \\
Salonenque & 70 & 100 & 3.0 & 4.5 & 2 \\
ZDH4 & 52 & 70 & 3.0 & 2.0 & 1 \\
\hline
\end{tabular}

$\bar{z} \% \mathrm{R}=$ rooting percentage, $\% \mathrm{C}=$ callusing percentage, $\mathrm{MRN}=$ mean root number, $\mathrm{MRL}=$ mean root length, $\mathrm{MLN}=$ mean leaf pair number. Experiment was performed once with at least six plants per cultivar.

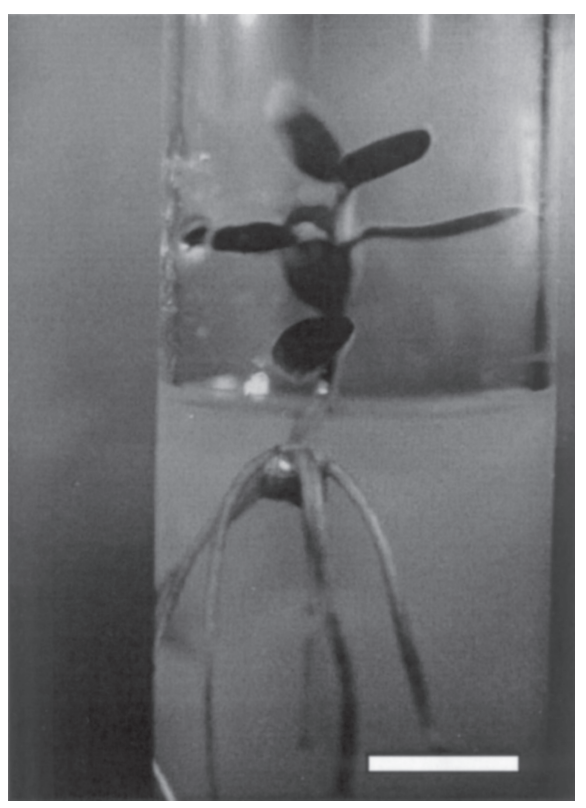

Fig. 3. Rooting obtained using the two-phase protocol 1 month after rooting initiation. $\mathrm{Bar}=1 \mathrm{~cm}$.

time that such difference in the lag phase has been reported. However, it was not checked under our conditions whether differences observed in the lag phase duration might also correspond to differences in subsequent shoot growth or multiplication rate. More extensive studies on additional cultivars could provide a genotype classification dependent upon lag phase duration.

The mean number of breaking buds varied between one and two. This latter figure compares favourably with that obtained in the Maurino cultivar (1.8) by Bartolini et al. (1990). Mean in vitro shoot growth was also shown to differ between the cultivars under the same culture conditions and greatly affected the multiplication rate. As only nodes at least $10 \mathrm{~mm}$ long could be subcultured, shoot elongation also had a direct impact on the multiplication rate independently of the numbers of nodes developed.

Budbreak induction was also found to be dependent upon the presence of growth regulators that clearly improved the in vitro multiplication response in all the cultivars, the results differing with regulator type and concentration

Treatments with BA alone or combined with NAA reduced the lag phase from $15 \mathrm{~d}$ in regulator-free medium to 11 and $10 \mathrm{~d}$ in the presence of the BA/NAA combination and BA alone, respectively. Mean budbreak was also increased (reaching 3) in the 'Dahbia' cultivar in the presence of BA. Since olive nodes normally comprise two axillary buds (Villemur and Delmas, 1982), this result suggests that BA induced simultaneously the development of both preexisting buds and bud neoforma-
Table 3. Effect of a reduced concentration of ZR on the multiplication rate of French olive cultivars. Results obtained from 30 explants per treatment, in two separate experiments

\begin{tabular}{lcc}
\hline & \multicolumn{2}{c}{ ZR } \\
\cline { 2 - 3 } Cultivar & $13.6 \mu \mathrm{M}$ & $4.6 \mu \mathrm{M}$ \\
\hline Amellau & 0.4 & 0.5 \\
Lucques & 0.4 & 0.4 \\
Picholine de Languedoc & 0.7 & 0.9 \\
Salonenque & 0.4 & 0.5 \\
\hline
\end{tabular}

tion. However, this treatment did not improve in vitro shoot growth, and thereby resulted in short shoots with internodes insufficiently long to allow their individual subculture. This was consistent with the work performed by Garcia-Fèrriz et al. (2002), advocating the introduction of an elongation phase to improve the multiplication rate.

Treatments with ZR reduced the lag phase even further to $7 \mathrm{~d}$. All resulted in a mean axillary budbreak that never exceeded two per node, while improving mean shoot growth (32 mm and 3 internodes developed) and the maximum multiplication rate $(\times 4)$. This confirmed the effectiveness of ZR compared to other treatments under our conditions, particularly in regard to primary shoot growth as reported by Rugini (1990) and Grigoriadou (2002).

However, microcuttings grown with ZR developed a large callus at the base, which might reduce shoot growth as reported in a similar study (Rugini and Fontanazza, 1981). Lowering the ZR concentration from 13.8 to $4.6 \mu \mathrm{M}$ did substantially reduce calli formations, but without a clear improvement in mean multiplication rate.

In vitro rooting of the new shoots was performed using two different protocols, with or without a separate induction phase in the dark. In the absence of the induction phase, no rooting was obtained for either of the cultivars tested, while all cultivars rooted to varying degrees with the two-phase protocol. The results obtained without an induction phase are likely to be due to a rooting inhibition in olive caused by continuous exposure to auxinlike regulators, particularly when used at high concentrations as shown for other ligneous families (Druart, 1997).

The best rooting rates were obtained in the 'Salonenque' (70\%) and 'Picholine marocaine' $(65 \%)$ cultivars. This latter result is particularly noteworthy considering the low in vivo reactivity of this genotype. Easy-to-root cultivars in horticultural practice, i.e., 'Salonenque', 'Lucques', 'Haouzia' and 'ZDH4' (Sghir et al., 2003), seemed to react similarly in vitro, with the exception of 'Lucques'. Picholine de Languedoc, never exceeding 25\% rooting (Sghir et al., 2003) with the traditional multiplication, reached $40 \%$ in vitro rooting.

Roots were observed to rise from the proximal part of the new shoot callus. In fact, rooting occurred simultaneously with callus production (70\% to $100 \%$ of the shoots), which did not seem to impair either root or shoot growth. The cultivars observed produced a mean of 3.2 roots that were a mean of $2 \mathrm{~cm}$ long, while mean leaf numbers ranged between 1 and 3 pairs. These results are comparable to those 
obtained in similar studies (Cozza et al, 1997; Grigoriadou, 2002; Wallali, 1993). However, a reduction in callus formation would certainly facilitate plantlet transfer to ex vitro conditions (Chaari Rkhiss et al., 2003).

We report here the first results obtained for the in vitro multiplication and rooting of Moroccan and French olive cultivars. Our data show that cultivar and growth regulators were the main factors modulating the response to in vitro multiplication and rooting. Multiplication would likely be improved alternating BA-induced bud multiplication with ZR-controlled elongation phases. It would also be of interest to check mother plants sanitary status to determine the actual influence of possible viruses and virus-like diseases on both horticultural and in vitro propagation.

\section{Literature cited}

Barranco, D., A. Cimato, P. Fiorino, L. Rallo, A. Touzani, C. Castañeda, F. Serafini, and I. Trujillo, 2000. Catalogue international de l'Olivier. Conseil Oléicole Intl., Madrid.

Bartolini, G., A.R. Leva, and A. Benelli. 1990. Advances in in vitro culture of olive: Propagation of cv Maurino. Acta Hort. 286:41-44.

Chaari, Rkhiss, A., M. Maalej, and N. Drira. 2003. Micropropagation des variétés tunisiennes d'olivier: Synthèse des résultats préliminaires. Olivae 95:19-24.

Cimato, A. 1999. Nursery production of olive plants, p. 1-30. In: Conseil Oléicole International (ed.). International Seminar on Scientific Innovations and their Applications to Olive Farming and Olive Oil technology. Conseil Oléicole Intl., Madrid.

Cozza, R., D. Turco, C. Briccoli Bati, and B. Bitonti. 1997. Influence of growth medium on mineral composition and leaf histology in micropropagated plantlets of Olea europaea. Plant Cell Tiss.
Org. Cult. 51:215-223.

Druart, P. 1997. Optimisation of culture media components for rooting Malus domestica Borkh. cv Compact Spartan in vitro. Biol. Plantarum 39(1):67-77.

Garcia, J.L., J. Troncoso, R. Sarmiento, and A. Troncoso. 2002. Influence of carbon source and concentration on the in vitro development of olive zygotic embryos and explants raised from them. Plant Cell Tiss. Org. Cult. 69(1):95-100.

Garcia-Fèrriz, L., R. Ghorbel, M. Ybarra,A. Mari,A. Belay, and I. Trujillo. 2002. Micropropagation of olive mature trees. Acta Hort. 586:879-882.

Grigoriadou, K., 2002. In vitro propagation of Greek olive cultivar "Chondrolia Chalkidikis". Plant Cell Tiss. Org. Cult. 71(1):47-54.

Kano, Y. and R. Nagata. 1999. Comparison of the rooting ability of virus infected and virus free cutting of sweet potatoes (Ipomoea batatas Poir.) and an anatomical comparison of the root. J. Hort. Sci. Biotechnol. 74 (6):785-790.

Leva, A.R., R. Petruccelli, and G. Bartolini. 1994. Mannitol in in vitro culture of Olea europaea $\mathrm{L}$. (cv. Maurino). Acta Hort. 356:43-46.

Leva, A.R., R. Petruccelli, R. Goretti, and M. Panicucci. 1992. Ruolo di alcuni microelementi e carboidrati nella proliferazione in vitro di $\mathrm{cv}$ di olivo (Olea europaea L.), p. 333-334. Proc. Intl. Congr. Olive oil quality, Firenze, 1-3 Dec.

Martelli, G.P., E. Zamboni., G. Zuccherelli, and M. Barba. 2001. L'organizzazione di un moderno vivaismo olivicolo alla base della productione di piante certificate. Frutticoltura 5:11-24.

Mencuccini, M. and E. Rugini. 1994. In vitro shoot regeneration from olive (Olea europaea L.) cultivar tissues. Plant Cell Tiss. Org. Cult. 32(3):283-288.

Miller, R.G.J. 1981. Simultaneous statistical inference. Springer Verlag, New York.

OEPP/EPPO. 1997. Pathogen-tested olive trees and rootstocks. OEPP/EPPO Bul. 27:185-195.

Ouazzani, N., R. Lumaret, and P. Villemur. 1996. Genetic variation in the olive tree (Olea europaea sativa L.) cultivated in the Morocco. Euphytica 91:9-20.

Rugini, E. and G. Fontanazza. 1981. In vitro propagation of 'Dolce Agogia' olive. HortScience 16(4):492-493.

Rugini, E. 1984. In vitro propagation of some olive (Olea europaea sativa L.) cultivars with different root-ability, and medium developement using analytical data from developing shoots and embryos. Scientia Hort. 24:123-134.

Rugini, E. and Fedeli E., 1990. Olive (Olea europaea L.) as an oilseed crop, p. 593-641. In: Y.P.S. Bajaj (ed.). Legumes and oilseed crops I. Biotechnology in agriculture and forestry. vol. 10. Springer, Berlin.

Rugini, E. and G. Pannelli. 1993. Olive (Olea europaea L.) biotechnology for short term genetic improvement. Agro Food Ind. Hi Tech 4(4):3-5.

Santos, C.V., G. Brito, G. Pinto, and H. Foncesca. 2003. In vitro plantlet regeneration of Olea europaea ssp. Maderensis. Scientia Hort. 97:83-87.

Seyhan, S. and E. Özzambak. 1994. Shoot multiplication of some olive (Olea europaea sativa L.) cultivars. Acta Hort. 356:35-38.

Sghir, S., I. Belkoura, and N. Ouazzani. 2003. Variabilité de l'aptitude rhizogène des varietés d'olivier (Olea europaea L.). Olivae 96:20-24.

Villemur, P. and J.M. Delmas. 1982. Croissance-développement chez l'olivier et alternance de production, p. 27-41. In : FAO (ed.). Séminaire sur l'olivier et autres plantes oléagineuses cultivées en Tunisie. Office National de l'huile, Tunis.

Wallali, L.D. 1993. La multiplication de l'olivier, p. 21-25. In: E. Meknès (ed.). IV. Cours international sur les nouvelles techniques oléicoles, Meknès.

Zuccherelli, G. and S. Zuccherelli. 2002. In vitro propagation of fifty olive cultivars. Acta Hort. 586:931-934. 